\title{
Elongated cells of Listeria monocytogenes in biofilms in the presence of sucrose and bacteriocin-producing Leuconostoc mesenteroides A11
}

\author{
Formação de células alongadas de L. monocytogenes em biofilmes na presença \\ de sacarose e Leuconostoc mesenteroides A11 produtor de bacteriocina
}

\author{
Regiane Priscilla RATTI ${ }^{1}$, Bruna Carrer GOMES ${ }^{1 \star}$, Rafael Chacon Ruiz MARTINEZ ${ }^{1}$, \\ Vanessa Maciel SOUZA ${ }^{1}$, Elaine Cristina Pereira De MARTINIS ${ }^{1}$
}

\begin{abstract}
Listeria monocytogenes is a foodborne pathogen which may survive in biofilms and persist in food processing plants. In this study, the ability of Leuconostoc mesenteroides ( $\mathrm{bac}^{+}$and $\mathrm{bac}^{-}$) to inhibit biofilm formation by L. monocytogenes ATCC 19115 was studied with stainless steel coupons immersed in BHI broth and BHI broth plus sucrose in combination with the Lactic Acid Bacteria (LAB). Adhered cells were collected with swabs and enumerated on selective agars (Oxford for listeria and MRS for leuconostoc). Leuconostoc mesenteroides bac ${ }^{+}$in co-culture with $L$. monocytogenes was effective to inhibit biofilm formation by listeria for up to 3 hours of incubation, but at 24 hours, biofilm was present in all conditions tested, as confirmed by observations of stainless steel coupons under Scanning Electron Microscopy (SEM). It was also observed that in the presence of $L$. mesenteroides bac $^{+}$in BHI plus sucrose, a high number of elongated cells of $L$. monocytogenes was present, which may indicate an adaptation response of the pathogen to stress conditions with important implications for food safety.

Keywords: L. monocytogenes; biofilm; elongated cells; lactic acid bacteria; bacteriocins.
\end{abstract}

\begin{abstract}
Resumo
Listeria monocytogenes é um patógeno transmitido por alimentos que apresenta a capacidade de sobreviver em biofilmes e persistir em plantas de processamento de alimentos. O presente trabalho avaliou a habilidade de Leuconostoc mesenteroides (bac ${ }^{+}$e bac be $^{-}$de inibir a formação de biofilme por L. monocytogenes ATCC 19115 em lâminas de aço inoxidável imersas em caldo BHI com ou sem sacarose em combinação com bactérias láticas (BAL). As células aderidas nas lâminas foram coletadas com swabs e enumeradas em meios seletivos (Oxford para listeria e MRS para leuconostoc). Leuconostoc mesenteroides bac ${ }^{+}$foi efetivo na inibição da formação de biofilme por L. monocytogenes por até 3 horas de incubação. Entretanto, após 24 horas de incubação, foi verificada a formação de biofilme em todas as condições testadas, conforme evidenciado pelas imagens obtidas por meio de Microscopia Eletrônica de Varredura (MEV). Adicionalmente, foi observado um elevado número de células de L. monocytogenes alongadas na presença de L. mesenteroides bac $^{+}$em BHI adicionado de sacarose, indicando uma resposta de adaptação do patógeno às condições de estresse, com importantes implicações para a segurança alimentar.

Palavras-chave: L. monocytogenes; biofilme; células alongadas; bactérias láticas; bacteriocinas.
\end{abstract}

\section{Introduction}

Listeria monocytogenes is a psychrotrophic Gram-positive pathogen that tolerates relatively high-salt concentrations and a wide $\mathrm{pH}$ range (5.0 to 9.0). It causes invasive listeriosis, a mainly foodborne disease that is a threat for immunocompromised individuals and during pregnancy, when it may lead to central nervous systems infections and abortion. However, more recently, gastroenteritis caused by L. monocytogenes has also been reported (DJORDJEVIC; WIEDMANN; McLANDSBOROUGH, 2002; MEAD et al., 1999; NORWOOD; GILMOUR, 1999; SCHLECH et al., 2005).

Contamination with L. monocytogenes in Ready-To-Eat (RTE) foods is of special concern because it can adhere to abiotic surfaces in food processing facilities creating a cellular mass that joins nutritious residues and other microorganisms forming biofilms (COSTERTON et al., 1995; LUNDÉN; AUTIO; KORKEALA, 2002; TOMPKIN, 2002; WONG, 1998).
L. monocytogenes can adapt to environmental stresses commonly found during food production and this favors its persistence in biofilms, which compromises food safety since adhered cells can be resistant to sanitizers and more difficult to detect and eliminate (ADRIÃO et al., 2008; BEREKSI et al., 2002; GIOTIS; BLAIR; McDOWELL, 2007; ZAIKA; FANELLI, 2003).

Morphological changes in bacterial cells may result as response to adverse conditions including exposure to acids, high $\mathrm{CO}_{2}$ concentration, high osmolarity, non optimum temperatures, and antimicrobial agents (BEREKSI et al., 2002; GIOTIS; BLAIR; McDOWELL, 2007; HAZELEGER; DALVOORDE; BEUMER, 2006; ISOM et al., 1995; JYDEGAARD-AXELSEN et al., 2005; LI et al., 2003; MINKOWISKI et al., 2001; NILSSON et al., 2000; ZAIKA; FANELLI, 2003). It has been reported that stress conditions may cause elongation of cells of several foodborne pathogens such as Salmonella, Escherichia coli, Bacillus,

Recebido para publicação em $7 / 11 / 2008$

Aceito para publicação em 8/7/2009 (003937)

Departamento de Análises Clínicas, Toxicológicas e Bromatológicas, Faculdade de Ciências Farmacêuticas de Ribeirão Preto, Universidade de São Paulo - USP,

Ribeirão Preto - SP, Brasil, E-mail: bruna.carrer@gmail.com

${ }^{*}$ A quem a correspondência deve ser enviada 
Clostridium and L. monocytogenes (EVERIS; BETTS, 2001; GILL; BADONI; JONES, 2007; HAZELEGER; DALVOORDE; BEUMER, 2006; JONES; GILL; McMULLEN, 2003; KIEBOOM et al., 2006).

Elongated cells may present an increased ability to adapt to subsequent stresses and can easily split up into single cells and start growing rapidly when transferred to more favourable conditions resulting in a highly contaminated food product (HAZELEGER; DALVOORDE; BEUMER, 2006; MATTICK et al., 2000; ZAIKA; FANELLI, 2003).

An alternative to prevent contamination of foods is the use of antimicrobial peptides named bacteriocins that may be active against spoilage and pathogenic bacteria such as L. monocytogenes. Some species of Leuconostoc can produce bacteriocins and are commonly used as starters in dairy fermentation (DE MARTINIS; FREITAS; SANTAROSA, 2003; KANG et al., 2007). Leuconostoc spp. comprises a group of heterofermentative LAB and some isolates synthesize extracellular polysaccharides (such as dextran from sucrose), which potentially interfere with biofilm formation (KANG et al., 2007).

In this paper, the ability of biofilm formation by L. monocytogenes on stainless steel coupons was evaluated in the presence of bacteriocin-producing and non bacteriocinproducing isolates of $L$. mesenteroides.

\section{Materials and methods}

\subsection{Bacterial cultures}

The bacterial cultures used were: Listeria monocytogenes ATCC 19115, Leuconostoc mesenteroides A11 (bac ${ }^{+}$, a bacteriocin-producing chicken isolate (DE MARTINIS et al., 2001), and the non bacteriocin-producing meat isolate Leuconostoc mesenteroides A13 ( $\mathrm{bac}^{-}$), kindly donated by Prof. Mariza Landgraf (Faculdade de Ciências Farmacêuticas, Universidade de São Paulo, Brazil). All cultures were kept in broths added of $20 \mathrm{~mL} .100 \mathrm{~mL}^{-1}$ of glycerol at $-70{ }^{\circ} \mathrm{C}$ : Brain Heart Infusion (BHI) for listeria and de Man Rogosa Sharpe (MRS) for leuconostoc (both from Oxoid, UK). The working cultures were prepared by inoculation of $1 \mathrm{ml}$ of stock suspension in $100 \mathrm{~mL}$ of suitable broth, followed by incubation for 24 hours at $37^{\circ} \mathrm{C}$ (listeria) and $25^{\circ} \mathrm{C}$ (leuconostoc).

\subsection{Stainless steel coupons}

Stainless steel coupons (AISI 340) of $15 \mathrm{~cm}^{2}(7.5 \times 2.0 \times$ $0.2 \mathrm{~cm}$ ) were washed and cleaned as previously described by Minei et al. (2008). For the experiments, up to 6 coupons were clamped vertically to a sterile stainless steel circular rack $(10 \mathrm{~cm}$ of diameter).

\subsection{Evaluation of biofilm formation on stainless steel coupons by pure culture of L. monocytogenes}

One set of rack and coupons was immersed in $100 \mathrm{~mL}$ of $\mathrm{BHI}$ broth containing ca. $10^{5} \mathrm{CFU} \cdot \mathrm{mL}^{-1}$ of an overnight culture of L. monocytogenes and incubated at $37^{\circ} \mathrm{C}$ for up to 48 hours. The coupons were removed after 3,24, and 48 hours and rinsed with $20 \mathrm{~mL}$ of Phosphate Buffer Saline (PBS) to remove nonadherent cells. The adherent cells were dislodged from each slide by rubbing with sterile cotton swab approximately 100 times. Individual swabs were transferred to tubes containing $10 \mathrm{~mL}$ of PBS and vortexed to suspend the cells in PBS. Serial decimal dilutions were prepared and surface plated on Trypticase Soy agar supplemented with $0.6 \mathrm{~g} .100 \mathrm{~mL}^{-1}$ of yeast extract (TSAYE, Oxoid - UK). The plates were incubated at $37^{\circ} \mathrm{C}$ for 24 hours to estimate L. monocytogenes population (CHAE; SCHRAFT, 2000; MARSH; LUO; WANG, 2003).

\subsection{Evaluation of biofilm formation on stainless steel coupons by a pure culture of L. mesenteroides}

One set of rack and coupons was immersed in $100 \mathrm{~mL}$ of BHI broth inoculated with $500 \mu \mathrm{l}$ of overnight cultures of either L. mesenteroides $\mathrm{bac}^{+}$or bac $\mathrm{bath}^{-}$Broths were incubated at $30{ }^{\circ} \mathrm{C}$ for up to 48 hours and the coupons were removed after 3,24 , and 48 hours and rinsed with $20 \mathrm{~mL}$ of PBS to remove non-adhered cells. The adherent cells were removed with swabs from the slides and plated as described above, but using MRS agar. The plates were incubated at $25^{\circ} \mathrm{C}$ for 48 hours to estimate populations of leuconostocs (CHAE; SCHRAFT, 2000; MARSH; LUO; WANG, 2003).

\subsection{Influence of co-culture with L. mesenteroides bac ${ }^{+}$ and bac on L. monocytogenes biofilm formation}

Working cultures of L. monocytogenes, L. mesenteroides $\mathrm{bac}^{+}$and $\mathrm{bac}^{-}$were prepared as described in item 2.1 and used to inoculate $(500 \mu \mathrm{l})$ BHI broth $(100 \mathrm{~mL})$ containing a set with rack and coupons under the following conditions: a) L. monocytogenes plus $L$. mesenteroides bac $^{+}$, b) L. monocytogenes plus $L$. mesenteroides bac'. Incubation was performed at $25^{\circ} \mathrm{C}$ for up to 48 hours, with removal of coupons after 3,24, and 48 hours to check for bacterial adherence. The slides were swabbed and serial decimal dilutions were prepared and surface plated $(100 \mu \mathrm{L})$ on MRS agar (leuconostoc) and Oxford agar (listeria). Incubation was performed respectively at 25 and $37^{\circ} \mathrm{C}$ for 24 hours. Additionally, the same experimental design was repeated using BHI broth added of $2 \mathrm{~g} .100 \mathrm{~mL}^{-1}$ sucrose (Synth, Brazil).

\subsection{Scanning Electron Microscope (SEM)}

Round stainless steel coupons $(1.2 \mathrm{~cm}$ diameter $)$ were prepared to be analyzed by SEM, and images were obtained at 24 hours of incubation as described by Minei et al. (2008).

\subsection{Statistical analysis}

The data presented are averages of three independent replicates and mean \pm standard deviation. To evaluate the differences among the treatments applied, one-way ANOVA with a significance level of $\mathrm{p}<0.05$ was used. When statistically significance difference among treatments was found, the Student's Newman Keuls test was applied with a significance level of $\mathrm{p}<0.05$. Analyses were performed using the software package SigmaStat 3.11 (SYSTAT, 2004). 


\section{Results and discussion}

It was previously demonstrated that dextrans produced by Leuconostoc spp. inhibited growth in vitro and formation of oral biofilms by Streptococcus mutans (KANG et al., 2007), and that the food isolate L. mesenteroides A11 presented antimicrobial activity towards $L$. monocytogenes (DE MARTINIS; FREITAS; SANTAROSA, 2003; MARTINEZ; DE MARTINIS, 2006). However, there are no reports in the literature on biofilm formation by $L$. monocytogenes in coculture with $L$. mesenteroides.

For the present study, biofilm formation was considered when at least $10^{3}$ cells were adhered per $\mathrm{cm}^{2}$ (WIRTANEN; HUSMARK; MATTILA-SANDHOLM, 1996). L. monocytogenes alone formed biofilm after 3 hours of incubation $\left(5.4 \log\right.$ CFU. $\left.\mathrm{cm}^{-2}\right)$ with increasing number of adhered cells at 24 hours ( $6.6 \log$ CFU. $\mathrm{cm}^{-2}$ ), followed by a decrease at 48 hours of incubation (5.8 $\log$ CFU.cm ${ }^{-2}$ ) (Figure 1). L. mesenteroides $\mathrm{bac}^{+}$did not adhere to the stainless steel coupons, whereas L. mesenteroides bac formed biofilm after 24 hours and presented a maximum number of adhered cells after 48 hours of incubation (5.9 log CFU.cm ${ }^{-2}$ ) (Figure 2).

When L. mesenteroides bac $^{+}$was co-cultivate with L. monocytogenes, it formed biofilm after 48 hours with $4.3 \log$ CFU. $\mathrm{cm}^{-2}$ (Figure 2). Moreover, it is important to note that co-culture with L. mesenteroides bac $^{+}$caused a reduction of up to $3.2 \log$ cycles in adhered population of L. monocytogenes (Figure 1) in the first 3 hours of incubation $(\mathrm{p}<0.001)$. After 24 hours of incubation, the number of adhered cells was still lower (6.1 log CFU.cm ${ }^{-2}$ ) than L. monocytogenes in pure culture $\left(6.6 \log\right.$ CFU. $\left.\mathrm{cm}^{-2}\right)$ with statistical significance $(\mathrm{p}<0.050)$. However, it was observed a significant $(\mathrm{p}=0.025)$ increase of the number of $L$. monocytogenes cells adhered to the stainless steel surface within 48 hours of incubation in the presence of L. mesenteroides bac ${ }^{+}$.

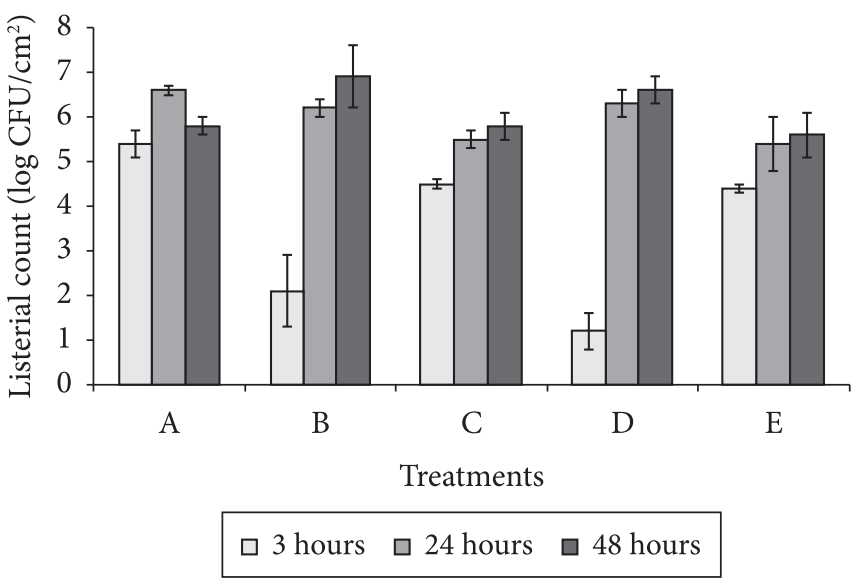

Figure 1. Biofilm formation by L. monocytogenes ATCC 19115 growing at $30{ }^{\circ} \mathrm{C}$ in $\mathrm{BHI}$ broth after 24 hours of incubation on stainless steel coupons: a) pure culture; b) co-culture with L. mesenteroides A11 ( $\left.\mathrm{bac}^{+}\right)$ and c) co-culture with L. mesenteroides A13 (bac'). L. monocytogenes ATCC 19115 growing at $30{ }^{\circ} \mathrm{C}$ in BHI broth added of sucrose (2 g.100 mL $\mathrm{m}^{-1}$ ) after 24 hours of incubation on stainless steel coupons: d) co-culture with L. mesenteroides A11 ( $\left.\mathrm{bac}^{+}\right)$; and e) co-culture with L. mesenteroides A13 ( $\left.\mathrm{bac}^{-}\right)$. Error bars indicate standard deviation from three independent experiments. Doted line indicates threshold value $\left(10^{3}\right.$ cells) considered as biofilm formation.
Biofilm formation by $L$. mesenteroides bac in co-culture with L. monocytogenes was observed after 24 hours of incubation with $5.8 \log$ CFU.cm ${ }^{-2}$ of adhered cells at 48 hours (Figure 2). Influence on biofilm formation by $L$. monocytogenes was not significant in the presence of L. mesenteroides bac' (Figure 1). For plate count results, there were not statistically significant differences among co-culture experiments carried out with BHI broth or BHI broth with sucrose (Figures 1 and 2).

Minei et al. (2008) evaluated the effect of LAB strains in the ability of biofilm formation by $L$. monocytogenes and revealed that when L. monocytogenes was co-cultured with E. faecium bac, in the early hours of incubation, the number of adhered L. monocytogenes cells was $2.5 \log$ lower compared with that in the control, but after 6 hours of incubation biofilm it was detected again. However, the co-culture of E. faecium $\mathrm{bac}^{+}$and L. monocytogenes did not allow biofilm formation.

According to Carpentier and Chassaing (2004), microorganisms present in food processing premises can either enhance or inhibit $L$. monocytogenes colonization on inert surfaces depending on the diversity and biochemical activity of accompanying microflora.

Several authors have applied SEM to analyze biofilms on abiotic surfaces (KALMOKOFF et al., 2001; MARSH; LUO; WANG, 2003; MOLTZ; MARTIN, 2005; MINEI et al., 2008). In this study, images captured by SEM showed that L. monocytogenes formed biofilm (ca. $10^{5}-10^{6}$ CFU. $\mathrm{cm}^{-2}$ ) within 24 hours of incubation on stainless steel coupons in all tested conditions (Figures 3 and 4), confirming data obtained

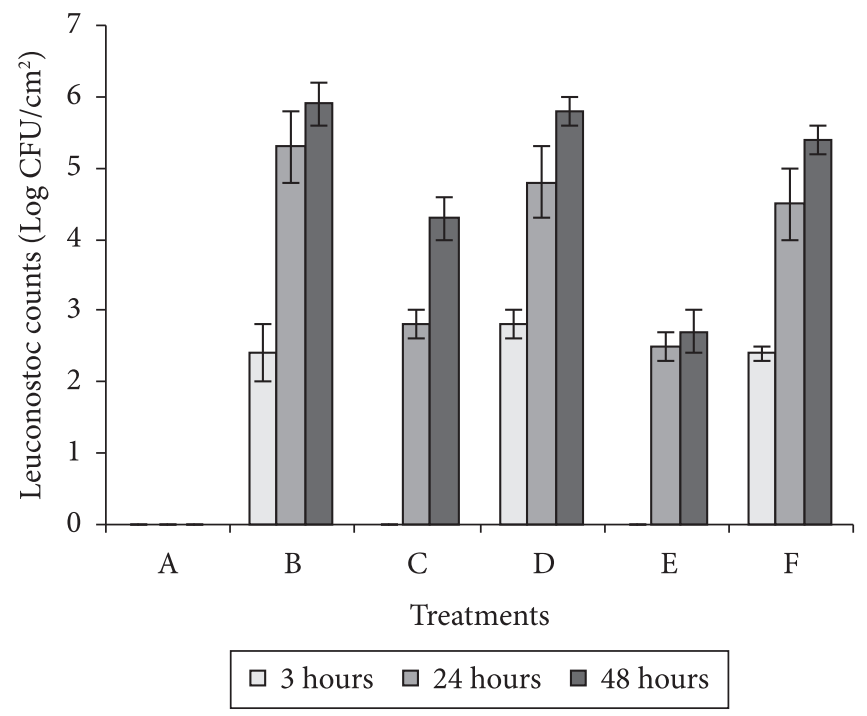

Figure 2. Biofilm formation by Leuconostoc A11 (bac ${ }^{+}$) after 24 hours of incubation at $30{ }^{\circ} \mathrm{C}$ on stainless steel coupons in BHI broth: a) pure culture; c) co-culture with L. monocytogenes ATCC 19115, and e) co-culture with L. monocytogenes ATCC 19115 in BHI broth added of sucrose ( $\left.2 \mathrm{~g} .100 \mathrm{~mL}^{-1}\right)$. Biofilm formation by L. mesenteroides A13 (bac') after 24 hours of incubation on stainless steel coupons: b) pure culture; d) co-culture with L. monocytogenes ATCC 19115, and f) co-culture with L. monocytogenes ATCC 19115 in BHI broth added of sucrose $\left(2 \mathrm{~g} .100 \mathrm{~mL}^{-1}\right)$. Error bars indicate standard deviation from three independent experiments. Doted line indicates threshold value $\left(10^{3}\right.$ cells) considered as biofilm formation. 

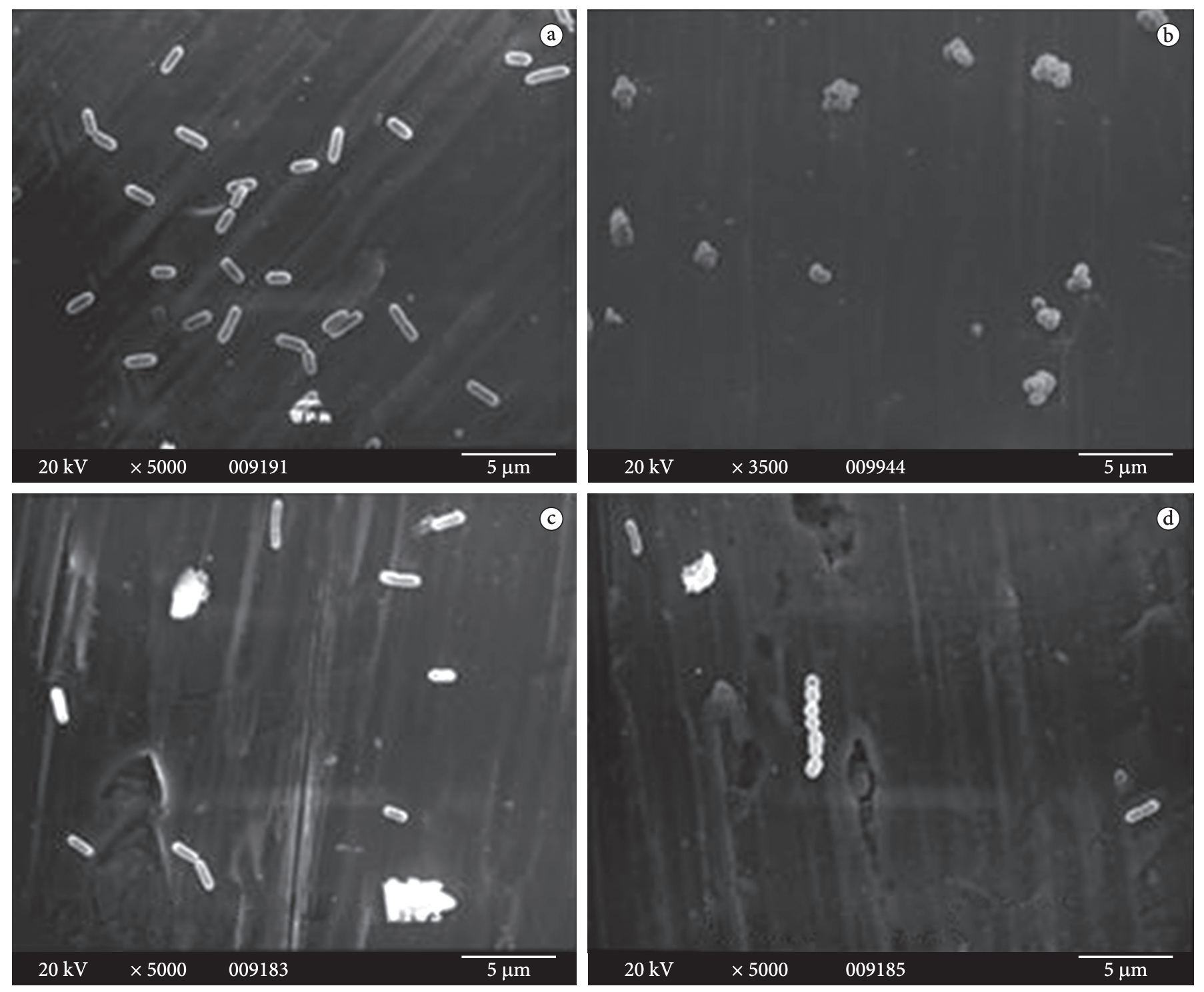

Figure 3. Scanning electron micrographics showing biofilm formation by a) pure culture of L. monocytogenes ATCC 19115; b) pure culture of L. mesenteroides A13 (bac); c) co-culture of L. monocytogenes ATCC 19115 plus L. mesenteroides A11 (bac ${ }^{+}$); and d) co-culture of L. monocytogenes ATCC 19115 plus L. mesenteroides A13 (bac') on stainless steel coupons after 24 hours of incubation at $30^{\circ} \mathrm{C}$ in BHI broth.

by the plate count method. L. monocytogenes in pure culture or co-cultivated with L. mesenteroides bac ${ }^{+}$in BHI broth without the addition of sucrose exhibited normal cell length of ca. $1.6 \mu \mathrm{m}$ (Figure 3a, c and d). Biofilm formation was observed for $L$. mesenteroides bac alone (Figure $3 \mathrm{~b}$ ), but not for L. mesenteroides bac ${ }^{+}$(data not shown).

Interestingly, elongated cells of L. monocytogenes (longer than $6.6 \mu \mathrm{m}$ ) were observed in biofilm in the presence of L. mesenteroides bac $^{+}$in BHI broth with sucrose (Figure 4a). Similar results were found by Kieboom et al. (2006) in a study on morphological changes and cell viability of Salmonella exposed to reduced water activity and different temperatures. Sucrose may be implicated with the formation of elongated cells since no morphological change was observed when L. monocytogenes was co-cultivated with $L$. mesenteroides bac $^{+}$without sucrose (Figure 3c).
Despite diverse studies on the effects of stress conditions in the morphology and viability of L. monocytogenes (HAZELEGER; DALVOORDE; BEUMER, 2006; ZAIKA; FANELLI, 2003), this is the first report on the effect of sucrose plus bacteriocin-producing lactic acid bacterium in the altered morphology of L. monocytogenes. According to Hazeleger, Dal Voorde and Beumer (2006), elongated cells of Listeria and Salmonella stained with DAPI (a nucleic acid stain) presented cell septa indicating that those cells were able to split up rapidly in single cells under more favorable conditions.

\section{Conclusions}

L. mesenteroides bac $^{+}$was more effective than L. mesenteroides bac in delaying biofilm formation by L. monocytogenes on stainless steel surface indicating its potential application to improve food safety. Sucrose and bacteriocins may influence the 

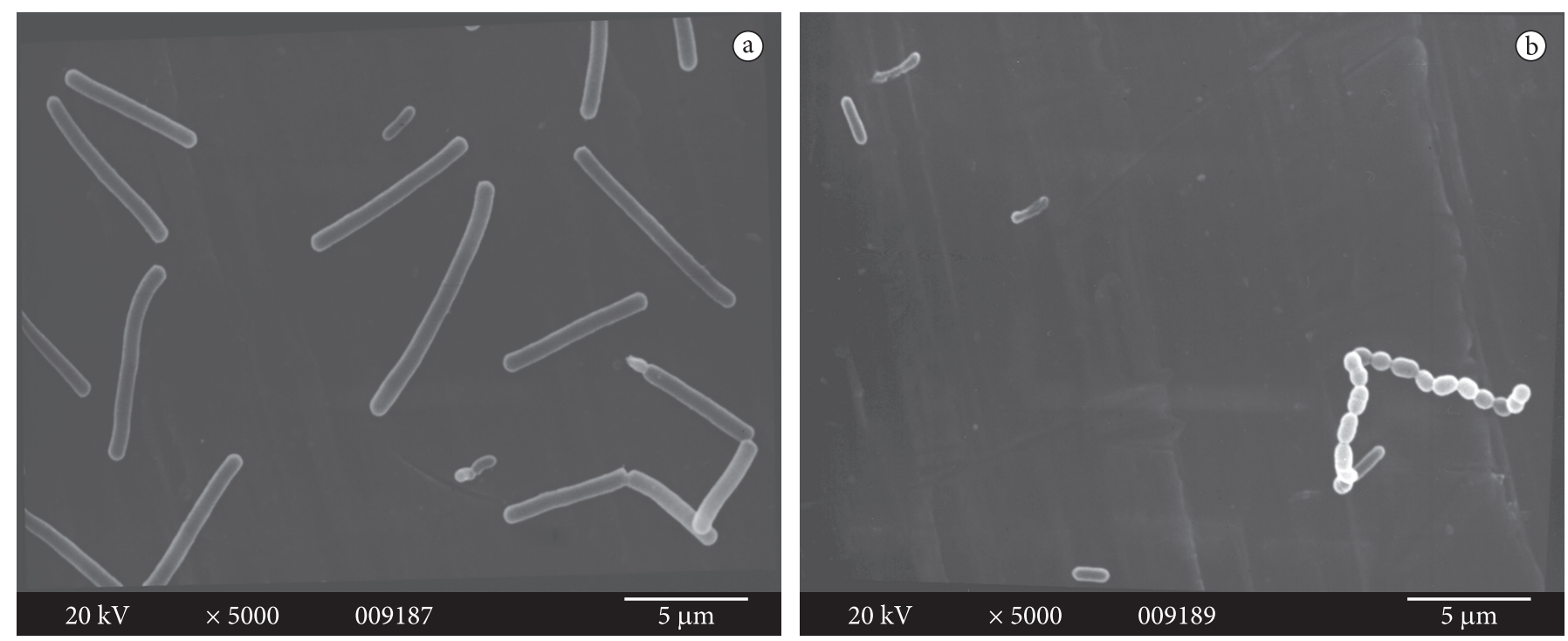

Figure 4. Scanning electron micrographics showing biofilm formation by a) co-culture of L. monocytogenes ATCC 19115 (elongated cells) plus L. mesenteroides A11 ( $\mathrm{bac}^{+}$) and b) co-culture of L. monocytogenes ATCC 19115, plus L. mesenteroides A13 (bac') on stainless steel coupons after 24 hours of incubation at $30{ }^{\circ} \mathrm{C}$ in $\mathrm{BHI}$ broth containing 2 g. $100 \mathrm{~mL}^{-1}$ of sucrose.

behavior of $L$. monocytogenes in food systems since the elongated cells of $L$. monocytogenes were observed and may indicate an adaptation mechanism to stress conditions.

\section{Acknowledgements}

The authors are grateful to Faculdade de Medicina de Ribeirão Preto - Universidade de São Paulo - Brazil, for the SEM analysis and for the technical assistance of M. D. Ferreira. The authors acknowledge the National Council for Scientific and Technological Development - Brazil for a research grant $(\mathrm{CNPq}$ \# 4804071/2004-5). Regiane. P. Ratti is grateful for the master's fellowship granted (CNPq \# 131087/2005-3).

\section{References}

ADRIÃO, A. et al. Marked intra-strain variation in response of Listeria monocytogenes dairy isolates to acid or salt stress and the effect of acid or salt adaptation on adherence to abiotic surfaces. International Journal of Food Microbiology, v. 123, p. 142-150, 2008.

BEREKSI, N. et al. Growth, morphology and surface properties of Listeria monocytogenes Scott A and LO28 under saline and acid environments. Journal of Applied Microbiology, v. 92, p. 556-565, 2002.

CARPENTIER, B.; CHASSAING, D. Interactions in biofilms between Listeria monocytogenes and resident microorganisms from food industry premises. International Journal of Food Microbiology, v. 97, p. 111-122, 2004.

CHAE, M. S.; SCHRAFT, H. Comparative evaluation of adhesion and biofilm formation of different Listeria monocytogenes strains. International Journal of Food Microbiology, v. 62, p. 103-111, 2000.

COSTERTON, J. W. et al. Microbial biofilms. Annual Reviews Microbiology, v. 49, p. 711-745, 1995.
DE MARTINIS, E. C. P. et al. Antilisterial activity of lactic bacteria isolated from vacuum-packaged Brazilian meat products. Brazilian Journal of Microbiology, v. 32, p. 32-37, 2001.

DE MARTINIS, E. C. P.; FREITAS, F. Z.; SANTAROSA, P. R. Caracterização preliminar de bacteriocinas produzidas por seis cepas de bactérias láticas isoladas de produtos cárneos embalados a vácuo. Ciência e Tecnologia de Alimentos, v. 23, p. 195-199, 2003.

DJORDJEVIC, D.; WIEDMANN, M.; McLANDSBOROUGH, L. A. Microtiter plate assay for assessment of Listeria monocytogenes biofilm formation. Applied Environmental Microbiology, v. 68, p. 2950-2958, 2002

EVERIS, L.; BETTS, G. pH stress can cause cell elongation in Bacillus and Clostridium species: a research note. Food Control, v. 12, p. 53-56, 2001.

GILL, C. O.; BADONI, M.; JONES, T. H. Behaviours of log phase cultures of eight strains of Escherichia coli incubated at temperatures of 2, 6, 8 and $10^{\circ} \mathrm{C}$. International Journal of Food Microbiology, v. 119, p. 200-206, 2007.

GIOTIS, E. S.; BLAIR, I. S.; McDOWELL, D. A. Morphological changes in Listeria monocytogenes subjected to sublethal alkaline stress. International Journal of Food Microbiology, v. 120, p. 250-258, 2007.

HAZELEGER, W. C.; DALVOORDE, M.; BEUMER, R. R. Fluorescence microscopy of NaCl-stressed, elongated Salmonella and Listeria cells reveals the presence of septa in filaments. International Journal of Food Microbiology, v. 112, p. 288-290, 2006.

ISOM, L. L. et al. Filament formation in Listeria monocytogenes. Journal of Food Protection, v. 58, p. 1031-1033, 1995.

JONES, T.; GILL, C. O.; McMULLEN, L. M. Behaviour of log-phase Escherichia coli at temperatures near the minimum for growth. International Journal of Food Microbiology, v. 88, p. 55-61, 2003.

JYDEGAARD-AXELSEN, A. M. et al. Changes in growth, rRNA content, and cell morphology of Listeria monocytogenes induced by $\mathrm{CO}_{2}$ up- and downshift. International Journal of Food Microbiology, v. 98, p. 145-155, 2005. 
KALMOKOFF, M. L. et al. Adsorption, attachment and biofilm formation among isolates of Listeria monocytogenes using model conditions. Journal of Applied Microbiology, v. 91, p. 725-734, 2001.

KANG, M. S. et al. Effect of Leuconostoc spp. on the formation of Streptococcus mutans biofilm. The Journal of Microbiology, v. 45, p. 291-296, 2007.

KIEBOOM, J. et al. Survival, elongation, and elevated tolerance of Salmonella enterica serovar Enteritidis at reduced water activity. Journal of Food Protection, v. 69, p. 2681-2686, 2006.

LI, J. et al. Cold and carbon dioxide used as multi-hurdle preservation do not induce appearance of viable but non-culturable Listeria monocytogenes. Journal of Applied Microbiology, v. 94, p. 48-53, 2003.

LUNDÉN, J. M.; AUTIO, T. J.; KORKEALA, H. J. Transfer of persistent Listeria monocytogenes contamination between food-processing plants associated with a dicing machine. Journal of Food Protection, v. 65, p. 1129-1133, 2002.

MARSH, E. J.; LUO, H.; WANG, H. A three-tiered approach to differentiate Listeria monocytogenes biofilm-forming abilities. FEMS Microbiology Letters, v. 228, p. 203-210, 2003.

MARTINEZ, R. C. R.; DE MARTINIS, E. C. P. Effect of Leuconostoc mesenteroides 11 bacteriocin in the multiplication control of Listeria monocytogenes $4 \mathrm{~b}$. Ciência e Tecnologia de Alimentos, v. 26, p. 52-55, 2006.

MATTICK, K. L. et al. Habituation of Salmonella spp. ate reduced water activity and its effect on heat tolerance. Applied and Environmental Microbiology, v. 66, p. 4921-4925, 2000.

MEAD, P. S. et al. Food-related ilness and death in the United States. Emerging Infectious Diseases, v. 5, p. 607-625, 1999.

MINEI, C. C. et al. Influence of peroxyacetic acid, nisin and co-culture with Enterococcus faecium on Listeria monocytogenes biofilm formation. Journal of Food Protection, v. 71, p. 634-638, 2008.
MINKOWISKI, P. et al. Effects of trimethoprim and co-trimoxazole on the morphology of Listeria monocytogenes in culture medium and after phagocytosis. Journal of Antimicrobials Chemotherapy, v. 48, p. 185-193, 2001.

MOLTZ, A. G.; MARTIN, S. E. Formation of biofilms by Listeria monocytogenes under various growth conditions. Journal of Food Protection, v. 68, p. 92-97, 2005.

NILSSON, L. et al. Carbon dioxide and nisin act synergistically on Listeria monocytogenes. Applied and Environmental Microbiology, v. 66, p. 769-774, 2000.

NORWOOD, D. E.; GILMOUR, A. Adherence of Listeria monocytogenes strains to stainless steel coupons. Journal of Applied Microbiology, v. 86, p. $576-582,1999$.

SCHLECH, W. F. III et al. Does Sporadic Listeria Gastroenteritis Exist? A 2-Year Population-Based Survey in Nova Scotia, Canada. Clinical Infectious Diseases, v. 41, p. 778-784, 2005.

SYSTAT 2004. SigmaStat for windows version 3.11. Systat Software Inc.

TOMPKIN, R. B. Control of Listeria monocytogenes in the food processing environment. Journal of Food Protection, v. 65, p. 709-725, 2002.

WIRTANEN, G.; HUSMARK, U.; MATTILA-SANDHOLM, T. Microbial evaluation of the biotransfer potential from surfaces with Bacillus biofilms after rinsing and cleaning procedures in closed food-processing systems. Journal of Food Protection, v. 59, p. 727-733, 1996.

WONG, A. C. L. Biofilms in food processing environments. Journal of Dairy Science, v. 81, p. 2765-2770, 1998.

ZAIKA, L. L.; FANELLI, J. S. Growth kinetics and cell morphology of Listeria monocytogenes scott $\mathrm{A}$ as affected by temperature, $\mathrm{NaCl}$, and EDTA. Journal of Food Protection, v. 66, p. 1208-1215, 2003. 